\title{
PERILAKU HARGA DAN PEMASARAN IKAN HASIL TANGKAPAN DI PROPINSI BENGKULU
}

\author{
Ketut Sukiyono ${ }^{1}$ \\ Harisma Ika Kaban ${ }^{2}$ \\ ${ }^{1}$ Staf Pengajar Jurusan Sosial Ekonomi Pertanian Fak. Pertanian UNIB \\ ${ }^{2}$ Alumni Jurusan Sosial Ekonomi Pertanian Fak. Pertanian UNIB
}

\begin{abstract}
The aims of this research are to analyze the market price of fish commodity and to forecast behaviour of fish price. Fish types that are analysed in this research are tongkol. The data consist of weekly data of tongkol in the four main market in Bengkulu for the period of 2002 to 2004 are used. The analysis of weekly prices used table analysis and linear regression model involving seasonal fishing dummies. Long run dynamic price equilibrium is analysed using linear regression model based on Cobweb model are estimated using OLS method while autocorrelation problems is overcome by Cochrane-Orcutt. From the trend analysis price tongkol fish result, it is concluded that the slope in Argamakmur and Curup was positive. Meanwhile, for tenggiri fish there was Bengkulu, Manna and Argamakmur that having a positive slope. Based on price behaviour estimation, it can be concluded that lagged price of tongkol is a signifikan factor in determining the fish price in all markets respectively. Moreover, marketing system analysed result that the price in Bengkulu market as a producer market has a signifikan influance to the price of fish in consumen market.
\end{abstract}

Key words: the market price, to forecast, behaviour

\section{PENDAHULUAN}

Sektor perikanan merupakan salah satu subsektor yang sangat penting untuk dikembangkan di samping subsektor pertanian pangan dan peternakan. Pembangunan di sektor perikanan sampai saat ini tetap diarahkan pada peningkatan kontribusi subsektor perikanan dalam menjamin tersedianya bahan pangan protein hewani, bahan baku industri, peningkatan eksport, meningkatkan pendapatan nelayan serta menunjang pembangunan daerah (Kusnadi, 2000)

Adapun pembangunan sektor perikanan adalah aktivitas pengelolaan sumberdaya perikanan yang bertujuan untuk meningkatkan produksi serta membawa manfaat sosial kepada masyarakat. Tujuan utama pembanguan sektor perikanan salah satunya adalah peningkatan pendapatan nelayan dan petani yang mengusahakan 
perikanan karena mereka sebagai kelompok sasaran pembangunan diharapkan dapat menjadi lebih baik status ekonominya dan dapat meningkatkan taraf hidup ke arah yang lebih layak dan sejahtera (Kusnadi, 2000).

Perikanan di Bengkulu sangat beragam karena masing-masing daerah mempunyai berbagai spesies komersial serta sumberdaya alam spesifik yang pemanfaatannya juga mengguanakan cara dan teknologi yang berbeda-beda. Produksi ikan menyangkut penangkapan dan pembudidayaan, baik di lingkungan laut, air tawar maupun tambak.

Perkembangan produk ikan tidak akan mempunyai arti jika produksi yang melimpah tidak dapat dipasarkan dengan baik atau dengan harga yang wajar. Dengan adanya fluktuasi produksi maka akan menyebabkan adanya fluktuasi harga pada ikan, artinya bahwa harga-harga pada suatu sistem pasar yang efisien cenderung bergerak bersama-sama. Gerakan harga bersama, musim bersama atau setiap faktor kebersamaan yang lain dapat memberikan perubahan harga yang selaras walaupun pasar-pasar tersebut tidak saling berhubungan. Maka dapat dirumuskan bahwa harga pada suatu pasar mempengaruhi harga pada pasar lain. Dengan adanya perbedaan perilaku harga komiditi ikan pada masing-masing pasar di setiap kabupaten, maka peneliti tertarik untuk melakukan penelitian mengenai perilaku harga dan pemasaran ikan laut hasil tangkapan di Propinsi Bengkulu. Penelitian ini bertujuan untuk mengetahui bagaimana trend harga pasar komoditi ikan, perilaku harga komoditi ikan di Propinsi Bengkulu serta sistem pemasarannya antara pasar konsumen dengan pasar producen

\section{METODE PENELITIAN}

Penelitian menggunakan data sekunder yaitu data-data harga mingguan di pasar kota Bengkulu, pasar kota Argamakmur, pasar kota Curup dan pasar kota Manna. Adapun metode analisa yang akan digunakan dalam penelitian ini adalah: 


\section{Metode Analisis Trend Harga}

Untuk mengetahui perkembangan harga komoditi ikan digunakan rumus trend linier :

$$
P f_{i j} \quad=a_{0}+a_{1} t+e t
$$

Dimana :

$$
\begin{aligned}
\mathrm{Pf}_{\mathrm{i}} & =\text { harga ikan pada waktu } \mathrm{t} \\
\mathrm{a}_{0} & =\text { konstanta/intersep } \\
\mathrm{a}_{1} & =\text { slope, nilainya dapat }(+) \text { bila trendnya cenderung } \\
& \text { semakin menaik atau (-) bila trendnya cenderung semakin } \\
& \text { menurun } \\
\mathrm{t} \quad & \text { menunjukkan satuan waktu yang besarnya sangat } \\
\mathrm{i} \quad & =\text { jitentukan oleh letak bulan dasarnya. } \\
\mathrm{j} & =\text { pasar dan lokasi pasar di tiap kota } \\
\text { et } \quad & \text { galat }
\end{aligned}
$$

\section{Metode analisis Perilaku Harga}

Dengan asumsi bahwa berlaku model Cobweb maka analisis harga dinamis jangka panjang menggunakan regresi linier berganda dengan model sebagai berikut :

$$
\mathrm{BR}_{\mathrm{t}}=\mathrm{b}_{0}+\mathrm{b}_{1} \mathrm{BR}_{(\mathrm{t}-1)}+\mathrm{b} 2 \mathrm{DM}+\mathrm{et}
$$

Dimana

$\mathrm{BR}_{\mathrm{t}}=$ Harga ikan di pasar kota Bengkulu pada minggu ke $\mathrm{t}$

$\mathrm{BR}_{(-1)}=$ Harga ikan di pasar kota Bengkulu pada minggu ke $\mathrm{t}-1$

$\mathrm{DM}$ = variable boneka sebagai proxy dari faktor musiman, diberi nilai 1 untuk musim tidak tangkap dan 0 untuk lainnya

Et = galat

Untuk menguji ketepatan model di uji dengan uji F, t, $\mathrm{R}^{2}$ dan durbin Watson.

\section{Metode Analisis Sistem Pemasaran}

Analisis struktur pasar menggunakan pedoman penggolongan pasar oleh Dahl dan Hammond (1972). Untuk analisis sistem pemasaran diestimasi model dasar 
hubungan antara pasar produsen dan pasar konsumen dengan model regresi sebagai berikut :

$$
\operatorname{Pr}_{\mathrm{t}}=\mathrm{c}_{0}+\mathrm{c}_{1} \mathrm{P}_{\mathrm{ft}}+\mathrm{c}_{2} \mathrm{DM}+\mathrm{e}_{\mathrm{t}}
$$

Dimana ;

$$
\begin{aligned}
\text { Pr }= & \text { harga di pasar konsumen di kota Argamakmur, kota Curup, dan kota } \\
& \text { Manna } \\
P_{\mathrm{f}}= & \text { harga di pasar produsen kota Bengkulu } \\
\mathrm{DM}= & \text { variabel boneka faktor musim, diberi nilai } 1 \text { untuk musim tidak tangkap } \\
& \text { dan } 0 \text { untuk lainnya } \\
\mathrm{t}= & \text { jumlah observasi } \\
\text { et } \quad & \text { galat }
\end{aligned}
$$

\section{HASIL DAN PEMBAHASAN}

\section{Analisis Trend Harga}

Hasil estimasi model trend harga masing-masing jenis ikan di Propinsi Bengkulu akan dibahas sebagai berikut :

a. Ikan Gembolo

Hasil estimasi model trend harga komoditi ikan gembolo disajikan pada Tabel 1 sebagai berikut :

Tabel 1 :Hasil dugaan model trend harga komoditi ikan gembolo

\begin{tabular}{lllll}
\hline \multirow{2}{*}{ Parameter } & \multicolumn{4}{c}{ Koefisien Regresi } \\
\cline { 2 - 5 } & Bengkulu & Manna & Argamakmur & Curup \\
\hline Konstanta & 13158,0 & 13467,0 & 9366,2 & 9240,80 \\
& $(1389,0)$ & $(637,90)$ & $(736,40)$ & $(530,40)$ \\
$\mathrm{T}$ & $-14,770$ & $-18,395^{\star * *}$ & $40,899^{\star * *}$ & $29,953^{\star * *}$ \\
& $(14,72)$ & $(6,985)$ & $(8,050)$ & $(5,791)$ \\
\hline $\mathrm{R}^{2}$ & 0,868 & 0,666 & 0,815 & 0,847 \\
$\mathrm{~F}_{\text {hitung }}$ & $11,655^{\star *}$ & $49,835^{\star *}$ & $18,534^{\star *}$ & $217,159^{* *}$ \\
$\mathrm{D}-\mathrm{W}$ & 2,196 & 2,176 & 2,240 & 2,134 \\
\hline
\end{tabular}

Keterangan: Angka dalam kurung menunjukkan standar error

$$
\begin{array}{rll}
\text { F Tabel : ** }: \text { Nyata pada taraf } 95 \%(152: 0,05) & =1,51 \\
\text { T Tabel : * }=\text { Nyata pada taraf } 90 \%(152: 0,10) & =1,645 \\
{ }^{* *}=\text { Nyata pada taraf } 95 \%(152: 0,05) & =1,960 \\
* * * \text { Nyata pada taraf } 99 \%(152: 0,01) & =2,576
\end{array}
$$

Hasil analisis menunjukkan bahwa slope untuk pasar Bengkulu dan Manna bernilai negatif. Artinya trend harga cenderung menurun. Ini berarti trend harga ikan 
gembola dimasa yang akan datang cenderung untuk menurun. Sedangkan nilai slope untuk pasar Argamakmur dan Curup bernilai positif, ini artinya trend harga cenderung meningkat. Implikasinya trend harga ikan gembolo dimasa yang akan datang cenderung meningkat. Trend harga menurun terjadi di daerah Bengkulu dan Manna. Hal ini disebabkan karena Pangkalan Pendaratan ikan (PPI) dan Tempat Pelelangan Ikan (TPI) banyak terdapat di daerah Bengkulu dan Manna, sementara untuk daerah Argamakmur dan Curup dikarenakan jarak tempuh antara Bengkulu Argamakmur, Bengkulu Curup relatif sulit sehingga Argamakmur dan Curup kurang mendapat pasokan ikan dari pasar Bengkulu. Karena kurangnya jumlah ikan yang terdapat di Argamakmur dan Curup menyebabkan harga ikan di daerah ini cenderung meningkat.

\section{b. Ikan Tongkol}

Dengan cara yang sama pada komoditi ikan gembolo, hasil estimasi model trend harga komoditi ikan tongkol disajikan pada Tabel 2

Tabel 2: Hasil dugaaan model trend harga komoditi ikan tongkol

\begin{tabular}{lllll}
\hline \multirow{2}{*}{ Parameter } & \multicolumn{4}{c}{ Koefisien Regresi } \\
\cline { 2 - 5 } Konstanta & Bengkulu & Manna & Argamakmur & Curup \\
& 10770,0 & 12471,0 & 10738,0 & 8904,10 \\
$\mathrm{~T}$ & $(240,0)$ & $(756,60)$ & $(1037,0)$ & $(961,50)$ \\
& $-4,568^{*}$ & $-11,657$ & $20,234^{*}$ & $37,573^{* * *}$ \\
\hline $\mathrm{R}^{2}$ & $(2,645)$ & $(8,273)$ & $(11,320)$ & $(10,19)$ \\
$\mathrm{F}_{\text {hitung }}$ & 0,256 & 0,638 & 0,692 & 0,948 \\
$\mathrm{D}-\mathrm{W}$ & $9,386^{* *}$ & $18,534^{* *}$ & $30,311^{* *}$ & $275,984^{* *}$ \\
\hline
\end{tabular}

Keterangan: Angka dalam kurung menunjukkan standar error

$$
\begin{array}{rrr}
\text { F Tabel : ** }: \text { Nyata pada taraf } 95 \%(152: 0,05) & =1,51 \\
\text { T Tabel : * }=\text { Nyata pada taraf } 90 \%(152: 0,10) & =1,645 \\
{ }^{* *}=\text { Nyata pada taraf } 95 \%(152: 0,05) & =1,960 \\
{ }^{* * *}=\text { Nyata pada taraf } 99 \%(152: 0,01) & =2,576 \\
\#=\text { Terdapat autokorelasi pada } \alpha=5 \% &
\end{array}
$$

Hasil estimasi dapat disimpulkan bahwa harga ikan tongkol di pasar Bengkulu dan Manna mempunyai kecenderungan menurun yang diindikasikan dengan tanda slope/koefisien regresi yang negatif. Sebaliknya, untuk kasus pasar Argamakmur dan 
Curup trend harga mempunyai kecenderungan yang naik. Trend harga meningkat terjadi di daerah Argamakmur dan Curup karena di daerah ini tidak terdapat atau jauh dari PPI dan TPI sehingga harus mendapat pasokan dari luar

Dengan menggunakan uji $\mathrm{F}$ maka diperoleh nilai $\mathrm{F}_{\text {hitung }}$ lebih besar dari nilai $\mathrm{F}_{\text {tabel }}$ pada taraf kepercayaan $95 \%$, sehingga tolak Ho dan terima Ha. Artinya nilai trend harga ikan tongkol pada bulan dasar berpengaruh nyata pada trend harga ikan pada waktu ke t.

\section{Hasil Analisis Model Perilaku Harga Ikan}

Hasil estimasi dari model perilaku harga ikan hasil tangkapan di Propinsi Bengkulu disajikan pada Tabel 3 dan 5 masing-masing untuk ikan gembolo dan tongkol

a. Ikan Gembolo

Hasil estimasi model perilaku harga komoditi ikan gembolo dengan autokorelasi dan tanpa aotokorelasi dengan menggunakan metode kuadrat terkecil disajikan pada Tabel 3 dan 4 sebagai berikut

Tabel 3 : Hasil dugaan model perilaku harga komoditi ikan gembolo

\begin{tabular}{lllll}
\hline \multirow{2}{*}{ Parameter } & \multicolumn{4}{c}{ Koefisien Regresi } \\
\cline { 2 - 5 } & Bengkulu & Manna & Argamakmur & Curup \\
\hline Konstanta & 778,460 & 2327,80 & 1442,30 & 948,490 \\
& $(362,70)$ & $(582,50)$ & $(474,90)$ & $(395,10)$ \\
$B_{(t-1)}$ & $0,934^{* * *}$ & $0,805^{* * *}$ & $0,890^{* * *}$ & $0,919^{* * *}$ \\
& $(0,029)$ & $(0,047)$ & $(0,036)$ & $(0,033)$ \\
$\mathrm{DM}$ & $-41,485$ & 210,570 & $-233,440$ & $-14,627$ \\
& $(186,30)$ & $(271,70)$ & $(285,40)$ & $(189,0)$ \\
\hline $\mathrm{R}^{2}$ & 0,8678 & 0,658 & 1442,3 & 948,49 \\
$\mathrm{~F}_{\text {hitung }}$ & $499,040^{* *}$ & $146,604^{* *}$ & $308.193^{* *}$ & $391,624^{* *}$ \\
Durbin-h & $-1,26$ & $-2,14^{\#}$ & $-2,10^{\#}$ & $-1,94^{\#}$ \\
\hline
\end{tabular}

Keterangan: Angka dalam kurung menunjukkan standar error

$$
\begin{array}{rrr}
\text { F Tabel : ** }: \text { Nyata pada taraf } 95 \%(152: 0,05) & =1,51 \\
\text { T Tabel }: * \text { Nyata pada taraf } 90 \%(152: 0,10) & =1,645 \\
{ }^{* *}=\text { Nyata pada taraf } 95 \%(152: 0,05) & =1,960 \\
{ }^{* * *}=\text { Nyata pada taraf } 99 \%(152: 0,01) & =2,576
\end{array}
$$


Hasil dugaan model perilaku ikan gembolo didapatkan bahwa autokorelasi terjadi di pasar Manna, Argamakmur dan Curup. Autokorelasi merupakan korelasi antara anggota seri observasi yang disusun menurut urutan waktu atau menurut urutan tempat. Cara yang dipakai untuk mendeteksi autokorelasi dalam penelitian ini adalah menggunakan uji durbin $\mathrm{h}$ statistik. Uji durbin $\mathrm{h}$ dilakukan dalam penelitian ini mengingat jumlah data observasi yang besar dan terdapat lag dari peubah tak bebas pada model yang dipakai

Salah satu cara pemecahan terhadap autokorelasi adalah dengan menggunakan metode Cohrane Orcutt. Metode ini secara garis besar menyebutkan perlunya dilakukan transformasi nilai peubah yang digunakan dalam model dengan memperhatikan besar kecilnya nilai korelasi $(\rho)$. Setelah ditransformasi maka data tersebut diolah kembali dengan menggunakan metode OLS. Perlu dicatat bahwa hasil estimasi ini menggunakan program Shazam dengan menggunakan fasilitas "auto" untuk menyelesaikan permasalahan autokorelasi (White, 1993). Hasil pendugaan disajikan pada Tabel 4

Hasil dugaan model perilaku ikan gembolo didapatkan bahwa autokorelasi terjadi di pasar Manna, Argamakmur dan Curup. Autokorelasi merupakan korelasi antara anggota seri observasi yang disusun menurut urutan waktu atau menurut urutan tempat. Cara yang dipakai untuk mendeteksi autokorelasi dalam penelitian ini adalah menggunakan uji durbin $\mathrm{h}$ statistik. Uji durbin $\mathrm{h}$ dilakukan dalam penelitian ini mengingat jumlah data observasi yang besar dan terdapat lag dari peubah tak bebas pada model yang dipakai

Salah satu cara pemecahan terhadap autokorelasi adalah dengan menggunakan metode Cohrane Orcutt. Metode ini secara garis besar menyebutkan perlunya dilakukan transformasi nilai peubah yang digunakan dalam model dengan memperhatikan besar kecilnya nilai korelasi $(\rho)$. Setelah ditransformasi maka data tersebut diolah kembali 
dengan menggunakan metode OLS. Perlu dicatat bahwa hasil estimasi ini menggunakan program Shazam dengan menggunakan fasilitas "auto" untuk menyelesaikan permasalahan autokorelasi (White, 1993). Hasil pendugaan disajikan pada Tabel 4

Tabel 4 : Hasil dugaan model perilaku harga komoditi ikan gembolo

\begin{tabular}{lllll}
\hline \multirow{2}{*}{ Parameter } & \multicolumn{4}{c}{ Koefisien Regresi } \\
\cline { 2 - 5 } & Bengkulu & Manna & Argamakmur & Curup \\
\hline Konstanta & 778,460 & 1489,80 & 957,580 & 623,930 \\
& $(362,70)$ & $(473,90)$ & $(388,20)$ & $(334,80)$ \\
$\mathrm{BR}_{(\mathrm{t}-1)}$ & $0,934^{* * *}$ & $0,875^{\star * *}$ & $0,928^{\star * *}$ & $0,947^{\star * *}$ \\
& $(0,029)$ & $(0,039)$ & $(0,039)$ & $(0,028)$ \\
$\mathrm{DM}$ & $-41,485$ & 175,780 & $-188,75$ & 39,812 \\
& $(186,30)$ & $(249,90)$ & $(264,50)$ & $(178,80)$ \\
\hline $\mathrm{R}^{2}$ & 0,867 & 0,674 & 0,811 & 0,842 \\
$\mathrm{~F}_{\text {hitung }}$ & $499,040^{* *}$ & $146,604^{* *}$ & $308.193^{* *}$ & $391,624^{* *}$ \\
DW & 2,202 & 2,090 & 2,076 & 2,068 \\
Durbin-h & $-1,26$ & $-0,56$ & $-0,47$ & $-0,42$ \\
\hline
\end{tabular}

Keterangan: Angka dalam kurung menunjukkan standar error

$$
\begin{array}{rlr}
\text { F Tabel }:{ }^{* *}: \text { Nyata pada taraf } 95 \%(152: 0,05) & =1,51 \\
\text { T Tabel }:{ }^{*}=\text { Nyata pada taraf } 90 \%(152: 0,10) & =1,645 \\
{ }^{* *}=\text { Nyata pada taraf } 95 \%(152: 0,05) & =1,960 \\
{ }^{* *}=\text { Nyata pada taraf } 99 \%(152: 0,01) & =2,576 \\
* \text { * Terdapat autokorelasi pada } \alpha=5 \% &
\end{array}
$$

Tabel 4 : Hasil dugaan model perilaku harga komoditi ikan gembolo

\begin{tabular}{lllll}
\hline \multirow{2}{*}{ Parameter } & \multicolumn{4}{c}{ Koefisien Regresi } \\
\cline { 2 - 5 } & Bengkulu & Manna & Argamakmur & Curup \\
\hline Konstanta & 778,460 & 1489,80 & 957,580 & 623,930 \\
& $(362,70)$ & $(473,90)$ & $(388,20)$ & $(334,80)$ \\
BR $_{(\mathrm{t}-1)}$ & $0,934^{* * *}$ & $0,875^{* * *}$ & $0,928^{\star * *}$ & $0,947^{\star * *}$ \\
& $(0,029)$ & $(0,039)$ & $(0,039)$ & $(0,028)$ \\
$\mathrm{DM}$ & $-41,485$ & 175,780 & $-188,75$ & 39,812 \\
& $(186,30)$ & $(249,90)$ & $(264,50)$ & $(178,80)$ \\
\hline $\mathrm{R}^{2}$ & 0,867 & 0,674 & 0,811 & 0,842 \\
$\mathrm{~F}_{\text {hitung }}$ & $499,040^{\star *}$ & $146,604^{* *}$ & $308.193^{* *}$ & $391,624^{* *}$ \\
DW & 2,202 & 2,090 & 2,076 & 2,068 \\
Durbin-h & $-1,26$ & $-0,56$ & $-0,47$ & $-0,42$ \\
\hline Ken
\end{tabular}

Keterangan: Angka dalam kurung menunjukkan standar error

$$
\begin{array}{rlr}
\text { F Tabel }:{ }^{* *}: \text { Nyata pada taraf } 95 \%(152: 0,05) & =1,51 \\
\text { T Tabel }:{ }^{*}=\text { Nyata pada taraf } 90 \%(152: 0,10) & =1,645 \\
{ }^{* *}=\text { Nyata pada taraf } 95 \%(152: 0,05) & =1,960 \\
{ }^{* * *}=\text { Nyata pada taraf } 99 \%(152: 0,01) & =2,576 \\
*=\text { Terdapat autokorelasi pada } \alpha=5 \% &
\end{array}
$$

Nilai koefisien determinan $\left(\mathrm{R}^{2}\right)$ untuk masing masing kota sebesar 0,867; 0,674;

0,811; dan 0,842 menunjukkan bahwa dua peubah bebas yang digunakan dalam model 
mampu menjelaskan perilaku harga ikan gembolo di empat pasar sebesar lebih dari $67 \%$, sisanya kurang dari $33 \%$ dijelaskan oleh peubah lainnya yang tidak dijelaskan dalam penelitian, misalnya jumlah permintaan, produksi.

Hasil penelitian menunjukkan bahwa perilaku harga ikan gembolo di pasar Bengkulu, Argamakmur, Manna dan Curup pada tahun sebelumnya berpengaruh nyata terhadap perilaku harga ikan gembolo pada waktu t. Kesimpulan ini ditunjukkan oleh hasil analisis uji $t$ terhadap peubahnya yaitu $\mathrm{BR}_{(\mathrm{t}-1)}$, dimana $\mathrm{t}_{\text {hitung }}$ lebih besar dari $\mathrm{t}_{\text {tabel }}$ pada taraf kepercayaan 99

Untuk komoditi ikan gembolo, hasil uji t menunjukkan bahwa nilai dummy (musim tidak tangkap) tidak berpengaruh nyata terhadap perilaku harga ikan gembolo di pasar Bengkulu, Argamakmur, Manna dan Curup. Hal ini ditunjukkan oleh hasil uji t terhadap peubahnya yaitu DM dimana $t_{\text {hitung }}$ lebih kecil dari $t_{\text {tabel }}$ pada setiap level signifikan.

b. Ikan Tongkol

Dengan cara yang sama seperti komoditi ikan gembolo, model perilaku harga ikan tongkol di Propinsi Bengkulu dapat dilihat pada Tabel 5

Tabel 5 : Hasil dugaan model perilaku harga komoditi ikan tongkol

\begin{tabular}{lllll}
\hline \multirow{2}{*}{ Parameter } & \multicolumn{4}{c}{ Koefisien Regresi } \\
\cline { 2 - 5 } & Bengkulu & Manna & Argamakmur & Curup \\
\hline Konstanta & 5525,40 & 2349,50 & 2151,30 & 423,96 \\
& $-733,901$ & $(572,30)$ & $(572,20)$ & $(226,00)$ \\
$\mathrm{BR}_{(\mathrm{t}-1)}$ & 0,468 & $0,794^{\star * *}$ & $0,826^{\star * *}$ & $0,968^{\star * \star}$ \\
& $(0,705)$ & $(0,048)$ & $(0,045)$ & $(0,018)$ \\
$\mathrm{DM}$ & 210,90 & 459,00 & $-260,170$ & $-173,670$ \\
& $(207,50)$ & $(284,20)$ & $(358,20)$ & $(129,00)$ \\
\hline $\mathrm{R}^{2}$ & 0,2499 & 0,641 & 0,688 & 0,948 \\
$\mathrm{~F}_{\text {hitung }}$ & $25,322^{\star *}$ & $136,067^{\star *}$ & $168,330^{\star *}$ & $1384,275^{\star *}$ \\
Durbin-h & $-2,87^{\#}$ & $-0,10$ & $-2,83^{\#}$ & $-0,05$ \\
\hline Ken
\end{tabular}

Keterangan: Angka dalam kurung menunjukkan standar error

F Tabel : ** : Nyata pada taraf $95 \%(152: 0,05) \quad=1,51$

T Tabel : * $=$ Nyata pada taraf $90 \%(152: 0,10) \quad=1,645$

** $=$ Nyata pada taraf $95 \%(152: 0,05) \quad=1,960$

${ }^{* * *}=$ Nyata pada taraf $99 \%(152: 0,01) \quad=2,576$

\# = Terdapat autokorelasi pada $\alpha=5 \%$ 
Tabel 5 menunjukkan adanya autokorelasi di pasar Manna dan pasar Curup. Cara mengatasi masalah autokorelasi yaitu dengan menggunakan metode Cochrane Orcutt seperti yang dijelaskan di atas. Tabel 6 berikut menyajikan hasil dugaan model dengan menggunakan metode Cochrane Orcutt.

Tabel 6 : Hasil dugaan model perilaku harga komoditi ikan tongkol

\begin{tabular}{lllll}
\hline \multirow{2}{*}{ Parameter } & \multicolumn{4}{c}{ Koefisien Regresi } \\
\cline { 2 - 5 } & Bengkulu & Manna & Argamakmur & Curup \\
\hline Konstanta & 2114,90 & 2349,50 & 1258,70 & 423,96 \\
& $(486,90)$ & $(572,30)$ & $(438,40)$ & $(226,00)$ \\
BR $_{(t-1)}$ & $0,798^{* * *}$ & $0,794^{\star * *}$ & $0,899^{* * *}$ & $0,968^{\star * *}$ \\
& $(0,047)$ & $(0,048)$ & $(0,034)$ & $(0,018)$ \\
$\mathrm{DM}$ & 18,614 & 459,00 & $-324,840$ & $-173,670$ \\
& $(153,60)$ & $(284,20)$ & $(316,7)$ & $(129,00)$ \\
\hline $\mathrm{R}^{2}$ & 0,411 & 0,641 & 0,712 & 0,948 \\
$\mathrm{~F}_{\text {hitung }}$ & $25,322^{\star *}$ & $136,067^{\star *}$ & $168,330^{* *}$ & $1384,275^{* *}$ \\
DW & 2,108 & 2,016 & 2,223 & 2,009 \\
Durbin-h & $-0,67$ & $-0,10$ & $-1,39$ & $-0,05$ \\
\hline
\end{tabular}

Keterangan: Angka dalam kurung menunjukkan standar error

$$
\begin{array}{rlr}
\text { F Tabel : }{ }^{* *} \text { : Nyata pada taraf } 95 \%(152: 0,05) & & =1,51 \\
\text { T Tabel : }{ }^{*} \text { Nyata pada taraf } 90 \%(152: 0,10) & =1,645 \\
{ }^{* *}=\text { Nyata pada taraf } 95 \%(152: 0,05) & =1,960 \\
{ }^{* * *}=\text { Nyata pada taraf } 99 \%(152: 0,01) & =2,576
\end{array}
$$

Dari hasil penelitian diperoleh nilai $\mathrm{F}_{\text {hitung }}$ lebih besar dari nilai $\mathrm{F}_{\text {Tabel }}$ pada taraf kepercayaan $95 \%$ sehingga dapat dinyatakan tolak Ho atau terima Ha. Hal ini berarti bahwa harga ikan tongkol di pasar konsumen yaitu pasar Manna, Argamakmur dan Curup berpengaruh nyata terhadap harga di pasar produsen yaitu pasar Bengkulu

Pada Tabel 6 dapat terlihat bahwa nilai koefisien determinani $\left(\mathrm{R}^{2}\right)$ yang diperoleh adalah sebesar 0,$411 ; 0,641 ; 0,712$; dan 0,948 . Artinya bahwa lebih dari $41 \%$ variasi dari keempat harga pasar sekarang dapat dijelaskan oleh kedua peubah bebas yang terdapat pada model dalam penelitian ini, sisanya kurang dari 59\% dijelaskan oleh peubah lainnya, seperti jumlah permintaan, jumlah produksi.

Hasil analisis uji t komoditi ikan tongkol terhadap peubahnya yaitu $\mathrm{BR}_{(\mathrm{t}-1)}$, memperlihatkan bahwa nilai $t_{\text {hitung }}$ lebih besar dibandingkan dengan nilai $t_{\text {tabel }}$ pada taraf kepercayaan 99\%. Hal ini menunjukkan bahwa harga ikan tongkol pada tahun 
sebelumnya berpengaruh nyata terhadap harga ikan tongkol saat ini $(\mathrm{t})$ untuk pasar Bengkulu, Manna, Argamakmur dan Curup.

Hasil analisis uji t terhadap peubahnya dalam hal ini DM diperoleh hasil yaitu terhitung sebesar 0,$12 ; 1,61 ;-1,02$; dan $-1,34$. Hasil ini menunjukkan bahwa nilai $t_{\text {hitung }}$ lebih besar dibandingkan dengan nilai $\mathrm{t}_{\text {tabel }}$ pada taraf kepercayaan $95 \%$ hanya terjadi di pasar Manna sehingga dapat dinyatakan tolak Ho atau terima Ha. Untuk pasar Bengkulu, Argamakmur dan Curup nilai $t_{\text {hitung }}$ lebih kecil dibandingkan dengan nilai $t_{\text {tabel }}$ pada setiap level signifikansi.

\section{Hasil Analisis Model Sistem Pemasaran}

Data harga yang digunakan adalah data harga riil dari tahun 2002 sampai tahun 2004. Hasil estimasi dari sistem pemasaran ikan di Propinsi Bengkulu disajikan sebagai berikut:

a. Sistem Pemasaran Ikan Gembolo

Hasil estimasi model sistem pemasaran ikan gembolo dengan dan tanpa autokorelasi disajikan pada Tabel 7 dan 8 sebagai berikut :

Tabel 7 : Hasil dugaan model sistem pemasaran komoditi ikan gembolo

\begin{tabular}{|c|c|c|c|}
\hline \multirow[t]{2}{*}{ Parameter } & \multicolumn{3}{|c|}{ Koefisien Regresi } \\
\hline & Manna & Argamakmur & Curup \\
\hline \multirow[t]{2}{*}{ Konstanta } & 4988,90 & 16896,0 & 17978,0 \\
\hline & $(673,10)$ & $(1164,0)$ & $(711,3)$ \\
\hline \multirow[t]{2}{*}{$\mathrm{Pf}$} & $0,581^{* * *}$ & $-0,345^{\star \star *}$ & $-0,524^{* * *}$ \\
\hline & $(0,054)$ & $(0,095)$ & $(0,058)$ \\
\hline \multirow[t]{2}{*}{ DM } & $658,44^{*}$ & $-1206,50^{\star *}$ & $-781,55^{\star *}$ \\
\hline & $(346,70)$ & $(599,80)$ & $(366,4)$ \\
\hline $\mathrm{R}^{2}$ & 0,435 & 0,105 & 13,657 \\
\hline $\mathrm{F}_{\text {hitung }}$ & $58,952^{\star *}$ & $9,068^{\star *}$ & $44,110^{\star *}$ \\
\hline D-W & $0,779^{\#}$ & $0,275^{\#}$ & $0,347^{\#}$ \\
\hline \multicolumn{4}{|c|}{ Tabel 7 : Hasil dugaan model sistem pemasaran komoditi ikan gembolo } \\
\hline \multirow[t]{2}{*}{ Parameter } & \multicolumn{3}{|c|}{ Koefisien Regresi } \\
\hline & Manna & Argamakmur & Curup \\
\hline \multirow[t]{2}{*}{ Konstanta } & 4988,90 & 16896,0 & 17978,0 \\
\hline & $(673,10)$ & $(1164,0)$ & $(711,3)$ \\
\hline \multirow[t]{2}{*}{ Pf } & $0,581^{* * *}$ & $-0,345^{\star \star \star}$ & $-0,524^{* * *}$ \\
\hline & $(0,054)$ & $(0,095)$ & $(0,058)$ \\
\hline \multirow[t]{2}{*}{ DM } & $658,44^{*}$ & $-1206,50^{\star *}$ & $-781,55^{* *}$ \\
\hline & $(346,70)$ & $(599,80)$ & $(366,4)$ \\
\hline $\mathrm{R}^{2}$ & 0,435 & 0,105 & 13,657 \\
\hline
\end{tabular}




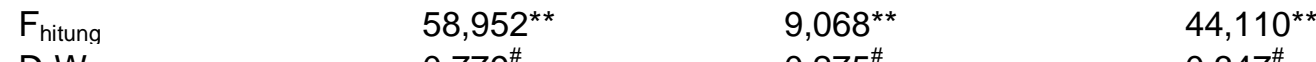

D-W $\quad 0,779^{\#} \quad 0,275$

Keterangan: Angka dalam kurung menunjukkan standar error

$0,347^{\#}$

F tabel : ** : Nyata pada taraf $95 \%(152: 0,05) \quad=1,51$

Hasil estimasi model harus diuji apakah terdapat autokorelasi atau tidak. Untuk melihat ada tidaknya autokorelasi, uji Durbin-Watson akan digunakan dalam penelitian ini. Nilai DW dari jenis ikan gembolo pada pasar Manna, Argamakmur dan Curup bernilai lebih kecil dari nilai $\mathrm{DW}_{\text {Tabel }}$ (Tabel 19). Berdasarkan hasil ini, dapat ditarik kesimpulan bahwa korelasi serial tampaknya merupakan suatu masalah dalam model ini. Cara untuk mengatasi persoalan autokorelasi digunakan pemecahan yang dirumuskan oleh Cochrane Orcutt. Dengan menggunakan alat analisis shazam, pada program shazam tersedia instruksi "auto" untuk menghilangkan autokorelasi. Hasil perbaikan dari autokorelasi dapat dilihat pada Tabel 8

Tabel 8 : Hasil dugaan model sistem pemasaran komoditi ikan gembolo

\begin{tabular}{llll}
\hline \multirow{2}{*}{ Parameter } & \multicolumn{3}{c}{ Koefisien Regresi } \\
\cline { 2 - 4 } & Manna & Argamakmur & Curup \\
\hline Konstanta & 8722,20 & 13118,0 & 12784,0 \\
& $(1239,0)$ & $(1677,0)$ & $(1143,0)$ \\
Pf & $0,272^{* * *}$ & $-0,436^{* * *}$ & $-0,092$ \\
& $(0,099)$ & $(0,122)$ & $(0,079)$ \\
DM & 219,58 & $-187,15$ & $-200,95$ \\
& $(233,30)$ & $(229,30)$ & $(148,1)$ \\
\hline$R^{2}$ & 0,636 & 0,802 & 0,840 \\
$F_{\text {hitung }}$ & $58,952^{* *}$ & $9,068^{* *}$ & $44,110^{* *}$ \\
D-W & 2,210 & 2,334 & 2,313 \\
\hline Ketran
\end{tabular}

Keterangan: Angka dalam kurung menunjukkan standar error

F Tabel : ** : Nyata pada taraf $95 \%(152: 0,05) \quad=1,51$

Keterangan: Angka dalam kurung menunjukkan standar error

F Tabel : ** : Nyata pada taraf $95 \%(152: 0,05) \quad=1,51$

Hasil estimasi ulang untuk model sistem pemasaran pada Tabel 16 nilai $\mathrm{R}^{2}$ didapat sebesar 0,$636 ; 0,802$; dan 0,804 . Artinya bahwa secara bersama-sama peubah penjelas mampu menjelaskan peubah yang dijelaskan sebesar lebih dari 63\%, sisanya kurang dari $37 \%$ dijelaskan oleh peubah lainnya yang tidak dimasukkan ke dalam model, misalnya jumlah permintaan. 
Dari hasil analisis uji $\mathrm{F}$ diperoleh nilai $\mathrm{F}_{\text {hitung }}$ sebesar 58,952; 9,068; dan 44,110. Selanjutnya, hasil perhitungan tersebut dibandingkan dengan $F_{\text {Tabel }}$ pada selang kepercayaan 95\%. Hasil perbandingan ini menunjukkan bahwa $\mathrm{F}_{\text {hitung }}$ lebih besar dari nilai $\mathrm{F}_{\text {Tabel }}$ sehingga dapat disimpulkan Ho ditolak atau Ha diterima. Atau dengan kata lain, model dapat digunakan untuk menggambarkan sistem pemasaran ikan gembolo di Propinsi Bengkulu.

Hasil analisis uji t terhadap peubahnya dalam hal ini Pf diperoleh hasil yaitu sebesar 2,$74 ;-3,57$; dan $-1,16$. Selanjutnya nilai $t_{\text {hitung }}$ tersebut dibandingkan dengan nilai $t_{\text {tabel }}$ pada selang kepercayaan 95\%. Maka dapat dinyatakan bahwa nilai $t_{\text {hitung }}$ lebih besar dibanding nilai tabel untuk pasar Manna dan Argamakmur, yang artinya secara statistik dapat dinyatakan bahwa Ho ditolak atau terima Ha.

Hasil uji t ini menunjukkan bahwa harga ikan gembolo di pasar Manna dan Argamakmur dipengaruhi secara nyata oleh harga di pasar Bengkulu sebagai pasar produsen. Sementara untuk pasar Curup nilai $t_{\text {hitung }}$ lebih kecil dibanding nilai $t_{\text {tabel }}$ pada setiap level signifikan, sehingga secara statistik dinyatakan bahwa tolak Ha dan terima Ho.

Berdasarkan nilai t terhadap peubah DM diperoleh besaran $\mathrm{t}$ masing-masing 0,94; -0,81; dan -1,35 untuk kasus si pasar Manna, Argamakmur dan Curup. Hasil uji t menunjukkan bahwa $t_{\text {hitung }}$ lebih kecil dari $t_{\text {tabel }}$ pada setiap level signifikan. Hasil ini dapat diartikan bahwa nilai dummy (musim tangkap) tidak berpengaruh nyata terhadap sistem pemasaran ikan gembolo di pasar Argamakmur, Manna dan Curup. Sehingga secara statistik dapat dinyatakan bahwa Ha ditolak atau terima Ho.

b. Sistem Pemasaran Ikan Tongkol 
Dengan cara yang sama seperti komoditi ikan gembolo, model sistem pemasaran ikan tongkol dengan autokorelasi dan tanpa autokorelasi di Propinsi Bengkulu dapat dilihat pada Tabel 9 dan 10

Tabel 9 : Hasil dugaan model sistem pemasaran komoditi ikan tongkol

\begin{tabular}{llll}
\hline \multirow{2}{*}{ Parameter } & \multicolumn{3}{c}{ Koefisien Regresi } \\
\cline { 2 - 4 } & Manna & Argamakmur & Curup \\
\hline Konstanta & 3241,60 & 21804,0 & 15780,0 \\
& $(1547,0)$ & $(2150,0)$ & $(1999,0)$ \\
Pf & $0,804^{* * *}$ & $-0,915^{* * *}$ & $-0,365^{*}$ \\
& $(0,150)$ & $(0,206)$ & $(0,192)$ \\
DM & 54,287 & $-456,87$ & $-483,87$ \\
& $(492,7)$ & $(607,20)$ & $(564,70)$ \\
\hline$R^{2}$ & 0,163 & 11,266 & 0,032 \\
$F_{\text {hitung }}$ & $14,909^{* *}$ & $11,090^{* *}$ & $2,556^{\star *}$ \\
D-W & $0,674^{\#}$ & $0,482^{\#}$ & $0,080^{\#}$ \\
\hline
\end{tabular}

Keterangan: Angka dalam kurung menunjukkan standar error

F tabel : ** : Nyata pada taraf $95 \%(152: 0,05) \quad=1,51$

Tabel 9 menunjukkan adanya autokorelasi pada pasar Manna, Argamakmur dan Curup. Cara mendeteksi autokorelasi pada model ini yaitu dengan menggunakan uji Durbin-Watson. Hasil estimasi ulang setelah menggunakan uji Durbin-Watson disajikan pada Tabel 10

Tabel 10 : Hasil dugaan model sistem pemasaran komoditi ikan tongkol

\begin{tabular}{llll}
\hline \multirow{2}{*}{ Parameter } & \multicolumn{3}{c}{ Koefisien Regresi } \\
\cline { 2 - 4 } & Manna & Argamakmur & Curup \\
\hline Konstanta & 11064,0 & 14326,0 & 12784,0 \\
& $(1192,0)$ & $(1495,0)$ & $(1143,0)$ \\
Pf & 0,044 & $-0,189$ & $-0,017$ \\
& $(0,107)$ & $(0,130)$ & $(0,044)$ \\
DM & 110,07 & $-43,625$ & $-150,71$ \\
& $(245,20)$ & $(298,20)$ & $(100,90)$ \\
\hline$R^{2}$ & 0,636 & 0,692 & 0,947 \\
$F_{\text {hitung }}$ & $14,909^{* *}$ & $11,090^{\star *}$ & $2,556^{\star *}$ \\
D-W & 1,941 & 2,379 & 1,832 \\
\hline
\end{tabular}

Keterangan: Angka dalam kurung menunjukkan standar error

F Tabel : ** : Nyata pada taraf $95 \%(152: 0,05) \quad=1,51$

Nilai koefisien determinan ikan tongkol menunjukkan bahwa faktor penduga sistem pemasaran yang digunakan mampu menjelaskan sistem pemasaran ikan tongkol di propinsi Bengkulu. Nilai F-hitung yang diperoleh lebih besar dari nilai F-Tabel pada selang kepercayaan 95\%, sehingga Ho ditolak dan Ha diterima. 
Pada Tabel 10 dapat dilihat bahwa hasil uji t terhadap peubahnya yaitu Pf diperoleh hasil sebesar 0,$41 ;-1,45$; dan $-, 0,38$, selanjutnya nilai $t_{\text {hitung }}$ dibandingkan dengan nilai $\mathrm{t}_{\text {tabel}}$. Maka dapat terlihat bahwa nilai $\mathrm{t}_{\text {hitung }}$ lebih kecil dari nilai $\mathrm{t}_{\text {tabel }}$ pada setiap level signifikan, yang secara statistik dapat diartikan bahwa terima Ho dan tolak Ha. Ini artinya bahwa pembentukan harga di pasar produsen (Manna, Argamakmur, Curup) tidak dipengaruhi oleh harga di pasar Bengkulu sebagai pasar produsen.

\section{KESIMPULAN DAN SARAN}

\section{Kesimpulan}

Berdasarkan hasil penelitian dan pembahasan yang telah dilakukan maka dapat ditarik kesimpulan

1. Slope positif ikan gembolo dan tongkol terjadi di pasar Argamakmur dan Curup. Sementara slope positif untuk ikan tenggiri terjadi di pasar Bengkulu, Manna dan Argamakmur.

2. Harga komoditi ikan gembolo dan ikan tongkol pada t-1 berpengaruh nyata terhadap pembentukan harga pada saat $\mathrm{t}$ di semua pasar (pasar kota Bengkulu, pasar Argamakmur, pasar Manna dan pasar Curup). Musim tangkap sebagai variabel boneka tidak berpengaruh nyata terhadap perilaku harga komoditi ikan di masing-masing pasar.

3. Harga komoditi ikan gembolo di pasar Manna dan Argamakmur sebagai pasar konsumen, dipengaruhi secara nyata oleh harga di pasar Bengkulu sebagai pasar produsen. Musim tangkap tidak berpengaruh nyata terhadap sistem pemasaran antara pasar konsumen dengan pasar produsen.

\section{Saran}

Dari hasil penelitian yang diperoleh maka peneliti memberikan saran

1. Perlu adanya tempat penyimpanan ikan (cold storage) agar pada waktu nelayan tidak melaut saat musim tangkap, persediaan ikan di pasaran masih mencukupi sehingga harga di pasaran tidak terlalu berfluktuatif.

2. Perlu adanya bantuan dari pemerintah untuk menyediakan sarana dan prasarana penunjang bagi nelayan dalam menjalankan profesinya sebagai nelayan penangkap ikan.

\section{DAFTAR PUSTAKA}


Bustami M. 2001. Peranan Pelelangan Ikan dalam Meningkatkan Pendapatan Nelayan. Makalah Falsafah Sains IPB.

Dahl, D. C. dan Hammond, J. W. 1997. Market and Price Analysis, The Agricultural Industries, Mc Graw - Hill Inc., United States Of America.

Elfindri dan Alfian Zein. 2001. Kredit untuk Nelayan dan Perbaikan Manajemen. Jurnal Ekonomi dan Pembangunan IX

Feliatra, DEA, 1998. Strategi Pembangunan Perikanan dan Kelautan Nasional dalam Meningkatkan Devisa Negara. Penerbit UNRI Press: Riau

Kartasapoetra, A. G. 1998. Pengantar Ekonomi Produksi. Cetakan Pertama Bina Aksara: Jakarta

Kotler, P dan G. Amstrong. 1997. Dasar-dasar Pemasaran (Anlisis, Perencanaan, Implementasi dan Kontrol). Edisi Bahasa Indonesia Jilid I, Ahli Bahasa Hendra.

Kusnadi. 2000. Nelayan, Strategi Adaptasi dan Jaringan Sosial. Momaniora Utama Press: Bandung.

Maria Hidajati dan Agus Hudoyo, 1997. Analisis Penentuan Harga Pokok Produksi dan Titik Impas pada Agroindustri Kecap (Studi Kasus pada Perusahaan Kacap Kawan Setia, Bandar Lampung). JPP Vol.IX No.8

Nikijuluw, dkk. 2000. dalam Potensi Usaha Perikanan Tangkap di Propinsi Bengkulu. Agrisep Vol 2.

Purwadi, Mas Soedjono dan Sri Widodo. 1993 Perilaku Harga dalam Pemasaran Bawang Merah. Buletin Ilmiah Instiper

Soekartawi. 2002. Prinsip Dasar Ekomoni Pertanian (Teori dan Aplikasi). Edisi Revisi. PT. Raja Grafindo Persada Press: Jakarta.

Soemarso SR, Drs. 1990. Peranan Harga Pokok dalam Penentuan Harga Jual. Penerbit Rineka Cipta: Jakarta

Sukirno, S. 1998. Pengantar Teori Mikroekonomi. Edisi 2. Raja Grafindo Persada: Jakarta

Supranto, J. 1985. Ekonometrik Jilid II. Fakultas Ekonomi. Universitas Indonesia: Jakarta

Tengku Dahril, 1998. Reformasi di Bidang Perikanan Menuju Perikanan Indinesia Yang Tangguh Abab ke-21. Penerbit UNRI Press : Riau.

Zarochman, 1996. Klasifikasi Alat Penangkapan Ikan yang sesuai dengan Perairan Indonesia.BPPI: Semarang 